\title{
Home Variables as correlates of University of Jos students aAchievement in Library and Information Science.
}

\author{
Ezeala, Lily Oluebube \\ Library \& Information Science UnitDepartment of Social Science Education, University of JosBox 190 Bukuru
}

\begin{abstract}
This study examined eight home environmental variables as they predict students' Academic achievement in library and Information Science course. The variables considered included warmth and democracy in the home, interactions between parents and children, language of communication at home relationship between the parents, parents aspiration of children's education, parents attitude to schooling, parents expectation of children's education and the availability and usage of instruction materials at home. An expost - facto descriptive survey research conducted. Years 1-3 level students of library and information science were used they were two hundred and eight (280) students. The instrument consisted of a valid home environmental variable questionnaire (HEVQ) an achievement test. The result of the study showed that eight home environmental variables, when taken together have high positive relationship with students' academic achievement in library and information science. $(\mathrm{R}=0.8522)$. The observed $\mathrm{F}=$ ratio is significant at 0.05 alpha level, which implies that $\mathrm{R}^{2}$ value of 0.7262 is not due to chance. Therefore, about $72.6 \%$ of the variance of students' achievement in library and information science is accounted for by a linear combination of the eight home environmental variables. However, five of the variables could be used to predict students' achievement in library and information science with availability and usage of instructional material at home being the most potent contributor to the prediction. In contrast to people's expectation, three variables namely, parents aspiration to children's education, parents expectations of their children's education and the language of communication at home made no significant contribution to die prediction of students' academic achievement in library and information science. Necessary recommendations were given in the paper.
\end{abstract}

\section{INTRODUCTION}

Scholars in the area of educational evaluation in the recent past seem to have shifted studies from the measure of individual to the measures of the environment. The reasons that could be adduced for this trend in development ranges between the accuracy of prediction which measures of environment could bring to learning to the possibility of manipulating the environment so as to bring about optimal conditions for learning.

Environment is usually seen in terms of social status characteristics such as the occupation and education of parents. It could also be seen in terms of family structure variables such as family size overcrowding ratio at home among others. Osokoya (2010) quoting keeves (19975) classified environmental factors into two, physical and psychological factors. The physical factors according to him include parental occupation and educational level, family type, number of children in the family, availability of instructional materials, relationship between the home and school and provision for studying at home. The psychological factor on the other hand includes attitudes of parents towards the child's education, parent's ambitions, hopes and aspirations for the child's future occupation.

Educational psychologists have noted the importance of environment in cognitive development of a child. Bloom (1964) sees the child's environment as providing a network of forces, which surround, engulf and play on the individual cognitive development to Bloom, measures of the child's environment is crucial for accurate prediction and effective manipulation of learning.

Walberg (1969) in the same vein sees environmental measures as prediction of cognitive, affective and behavioral measures of learning. Okoye (1981) describes environment as phenotypic. Environment to him plays the role of both physical and biological factors, which, while being outside the learner affect his performances. Internationally, persons like Carlson (1968); Barbara (1982) to mention a few all concluded that the child's environment influence attainment at school. Much had also been done locally to predict measures which environment could bring to learning.Touray (1982) Idowu (1990), Osokoya (2010). Most of these studies have suggested that home environmental variables could be manipulated to enhance pupils' academic achievement. The various studies however, examined through a univariateapproach the influence of three or four home variables on academic achievement except Osokoya who studies eight but on history subject in secondary school. To the best knowledge of the researcher, none of such home environmental variable as correlate of academic achievement has been investigated in University library and information science teaching in Nigeria. This background emphasizes the need to bring to focus the present study, which examined eight home 
environmental variables, as they predict student's academic achievement in library and information science. It is the contention of the investigation that a better understanding of the interaction between the six environmental variables and library and information science arraignment at the university level, especially when the environmental variables are taken together would be of considerable measure in improving the accuracy of prediction of library and information science learning while lecturer of library and information science would be in a better position to manipulate the environment to bring about optimal conditions for learning the course. This is particularly necessary at this period of time when the course is being introduced in the University of Jos.

Specifically, the study provided answer to the following questions.

1. To what extent would the six environmental variables, when taken together, predict choice of library and information science course in university?

2. What is the relative contribution of the variables to the prediction?

\section{RESEARCH DESIGN}

An expost-facto descriptive research was conducted. The home environmental variables for the study were.

1. Interaction between parents and children.

2. Relationshipbetweenbothparents.

3. Parents interest and attitude to schooling

4. Parents aspiration to educate their children

5. Language of communication at home

6. Parentsexpectation of children'seducation

7. Availability and usage of instructional materials at home

8. Warmth and democracy in the home

\section{METHODOLOGY}

a. Sample: The investigator stratified the library and information science students on the basis of their academic levels (Year 1, 2, \& 3). In all, therewere 280 studentsselected at random.

\section{INSTRUMENTATION}

Two valid and reliable instruments were used to collect date for the study.

1. Home Environmental variables questionnaire (HEVQ): The HEVQ was constructed by the researcher and validated in Jos. It was designed to find out the relationship between home environmental variables and the cognitive achievement of the students in library and information science. It was also designed to find out which of the variables could predict achievement of students in library and information science.

The instrument is in three parts.

Part 1: The first part comprised of 12 items and it was to collect information about each students parental educational and occupational levels.

Part11:The second part was made up of 12 items and it was to collect information about the learning environment of the students at home.

Part III:The last section was made up of another 12 items and it was designed to elicit response from the students about their experiences and feelings at home.

The reliability of the Home Environmental variable Questionnaire was established at 0.67 using Cronbachalpha. 2. The achievement test was made up of 80 item test based on the content of their course outline.The topics were given by the unit as having been taught. The instrument was constructed by the researcher and it was validated by evaluation experts from University of Jos. The reliability was calculated to be 0.67 through test-retest methods after an interval of one week of administration to fifty students drawn from a school not located in the local government of the study.

\section{DATA COLLECTION AND ANALYSIS}

The instruments were administered directly to the students by the researcher. Data collection lasted for one week.Data analysis involved using multiple regression analysis (background elimination) to examine the relationship between the eight home environmental variables (independent variables) and achievement in library and information science (dependent variable).

\section{RESULT}

Composite effects of independent variables on dependent variable

Multiple R (adjusted) $=0.8522$

Multiple $\mathrm{R}^{2}$ (adjusted) $=0.7262$ 
Standard Error of Estimate $=8.59$

Table I: Analysis of Variance

\begin{tabular}{|l|l|l|l|l|}
\hline Source of Variance & df & Ss & ms & F-ratio \\
\hline Duetoregression & 8 & 12481.7 & 12435.21 & 198.64 \\
\hline Dueto residual & 271 & 19739.6 & 72.84 & \\
\hline Total & 279 & 119221.3 & & \\
\hline
\end{tabular}

The eight home environmental variables together correlate 0.8522 with the dependent variable.These variables also account dependent variable $\left(R^{2}=0.7262\right)$. The table also shows a significant F-ratio of 198.64 , which implies that, the $\mathrm{R}^{2}$ value is not due to chance.

Table 2.Relative contribution of the independent variables to student's library and information science achievement

\begin{tabular}{|l|l|l|l|l|l|l|}
\hline Variable No & Variable & $\begin{array}{l}\text { Std. } \\
\text { Regwt.( } \\
\text { B) }\end{array}$ & SEB & DF & T-Value & P-value \\
\hline 1 & $\begin{array}{l}\text { Warmth and democracy in the } \\
\text { home }\end{array}$ & 0.2845 & 0.06 & 5.247 & 6.12 & 0.05 \\
\hline 2 & $\begin{array}{l}\text { Parents interest and attitude to } \\
\text { schooling }\end{array}$ & 0.1525 & 0.04 & 6.142 & 5.72 & 0.05 \\
\hline 3 & $\begin{array}{l}\text { Language of communication at } \\
\text { home }\end{array}$ & 0.0342 & 0.02 & 1.024 & 1.32 & NS \\
\hline 4 & $\begin{array}{l}\text { Relationshipbetweentheparent } \\
\text { s }\end{array}$ & 0.1292 & 0.05 & 3.264 & 2.76 & 0.05 \\
\hline 5 & $\begin{array}{l}\text { Parents expectation of } \\
\text { children's education }\end{array}$ & 0.0412 & 0.03 & 7.245 & 1.38 & NS \\
\hline 6 & $\begin{array}{l}\text { Availability and usage of } \\
\text { instructional material at home }\end{array}$ & 0.3492 & 0.04 & 4.425 & 5.12 & 0.05 \\
\hline 7 & $\begin{array}{l}\text { Parents aspiration of children's } \\
\text { education }\end{array}$ & 0.0546 & 0.02 & 2.324 & 1.27 & NS \\
\hline 8 & $\begin{array}{l}\text { Interaction between parents } \\
\text { and children }\end{array}$ & 0.2152 & 0.05 & 5.242 & 8.24 & 0.05 \\
\hline
\end{tabular}

Table 2 shows for each independent variable, the standardized regression weight (B) the standard error estimate (SEB), the degree of freedom (DF) the T-value and the probability values. Only the independent variable whose $\mathrm{B}$ value has significant $\mathrm{T}$-value could predict the dependent variable.According to the table values, five of them fell in this category. In this case, the T-value associated with only one variable 1 , (warmth and democracy at home), 2, (parents interest and attitude to schooling) 4, (relationship between the parents) 6, (availability and usage of instructional materials at home and 8, (interaction between parents and children) could be used to predict the dependent variable.

\section{DISCUSSION}

The results of the present study revealed that the eight home environmental variables, when taken together, seem to be effective in predicting undergraduates student academic performance in Library and Information Science The observe F-ratio is significant at 0.05 alpha level- an indication that the R2 of 0.7262 could not have been due to chance. The magnitude of correlation coefficient (0.8522) indicates that the eight variables correlated well with the dependent variable. It could thus be said that about $72.6 \%$ of variance of students' attainment in Library and Information Science at the University level was accounted for by a linear combination of the eight home environmental variables. As for the extent to which each of the eight independent variables contributed to the prediction, the value of the $\mathrm{T}$ associated with each variable, as shown in Table 2, indicated that only five of the variables could be used to predict student's achievement in undergraduate Library and Information Science students. The variables are variable 1,2,4,6 and 8. The values of the standardized regression weight associated with these variables (see Table 2) indicate that variable 6 is the most potent contributor to the prediction followed by variable 1,8 and 2 .The findings of this study have shown that the home environment of a child is a possible source of explanation for a child's academic achievement in schools particularly Library and Information Science course. The availability and usage of instructional materials at 
home is very crucial for students' academic achievements in school. The students provided with adequate learning materials at home are likely to excel than the students provided with no suitable learning environment. The students provided with reading room containing Internet, textbooks, journals, periodicals, magazines, charts, newspapers are likely to perform better and achieve higher than the students provided with no learning materials because all the tools necessary for easy learning are adequately provided for at home. The availability of instructional materials at home would afford the students opportunity to read more and get more facts about the topics treated in the school and thus improve their mastery of the course.

The study had clearly shown that warmth and democracy in the home could improve academic achievements of students. Part of psychological and conducive home environment necessary for better learning is warmth and democracy in the home. Going by the partial standard regression weight (B) the study shows that a unit change in availability and usage of instructional materials would give 0.35 changes in students' achievement in Library and Information Science. Similarly, a unit change in warmth and democracy in the home would lead to 0.28 changes in achievement. Furthermore, a unit change in parents' interest and attitude to schooling, relationship between the parents' and interaction between parents and children would result in 0.15 ; 0.13 and 0.22 changes in students' academic achievement in Library and Information Science respectively. Furthermore, a warm relationship between the parents and their children would give the children emotional stability which is a sine-qua-non for effective learning and better academic achievement (Weber (1975).

The study also indicated the strength of the relationship of parents' interest and attitude to learning in the determination of their children's academic achievement in general and in Library and Information course in particular. These findings support previous studies like those of Hunt (1961); Bloom (1964) Hake (1972) and Osokoya (2010) that active involvement of parents in academic progress of their children has always yielded positive results. In contrast to expectation, parents' aspirations and expectation of their children's education made no significant contribution to the prediction of academic achievement in Library and Information Science course. The language of communication at home also made no significant contribution to the prediction of students' attainment in Library course. This, perhaps, is an indication that in the presence of other more potent home environmental variables, the respective contribution of the three variables to the reduction would be low and not statistically significant.

\section{CONCLUSION}

The results reported in this study proved an empirical basis for suggesting that Library Science teachers and counsellors should take into cognizance the eight home environmental variables used in this study.

For a higher attainment in Library Science course, effective rapport and good relationship between the parents should be encouraged. Adequate knowledge of the students' home environment variables would enable the Library Science students to identify students' problems and also proffer solutions to environmental problems that could inhibit their learning.

\section{REFERENCES}

[1] Bloom, B.S (1964); Stability and Change in Human Characteristics. New York Wiley.

[2] Hake, J. (1972): Child Rearing Practice in Northern Nigeria. Ibadan, University Press.

[3] Hunt, J. (1961): Intelligence and Experience, New York. Ronald Press.

[4] Okoye, N.N (1981): The Psychology of Effective Learning; (Monographed) Dept. of Guidance and Counselling University of Ibadan.

[5] Osokoya, I.O. (2010): Teaching and Researching History in Nigeria. University of Ibadan.

[6] Touray, S.K. (1982): Home environment and Academic Achievement among form one pupil in Ibadan Secondary Schools. Unpublished M.Phil dissertation, University of Ibadan.

[7] Walberg, H.J. (1969): Social environment as a mediator of classroom learning. Journal of Educational Psychology 60, 443-448.

[8] Weber, M. (1975): Psychology in Africa, International African Institute. 